\title{
Differential Roles between Owner and Manager in Financial Practice that Contributes to Business Success: an Analysis on Malaysian Small Business
}

\author{
S. M. Ferdous Azam \\ PhD Research Fellow, Department of Business Administration, \\ Kulliyyah of Economics and Management Sciences, International Islamic University Malaysia \\ sakeeb06@gmail.com \\ Moha A. Abdullah \\ Professor, Department of Economics, Faculty of Economics and Management Sciences, \\ International Islamic University Malaysia \\ mosria@gmail.com
}

\section{Doi:10.5901/ajis.2015.v4n1s2p123}

\section{Abstract}

\begin{abstract}
The purpose of this research is to assess the moderating effect of business owner and manager in financial practice towards business success in Malaysian small business. To meet the research objectives, this study employed survey method where the unit of analysis is the individual respondent consisting business owners and managers. A sample of 302 data was considered as the final sample size for the current study. Using Structural Equation Modelling (SEM), moderating effects were observed to test the hypotheses. The results indicate that, the owners and managers do have different moderating roles in financial practice to guide the business success in Malaysian small business. Thus, this research conveys an understanding to the entrepreneurs regarding the difference of ownership and managerial role to achieve the business success swiftly. Finally, the current study brings some implications to the policy makers and regulators as well.
\end{abstract}

Keywords: Business Owner, Business manager, Moderating role, Financial practice, Business success, Malaysian small business

\section{Introduction}

The Malaysian small businesses are presently having a good business and their overall performance somehow be said as expected (Khairudin, 2007; Moha Asri and Manan, 2010). Statistically, it is estimated that the share of employment by small business will increase close to 60 percent in the near future (SMEs Annual Report, 2012). Actually, the strong employment growth of small business began in 2007 at 8.3 percent, when the value added growth of small business was at its peak (SMEs Annual Report, 2012). Literatures and statistical records (Lim, 1986; Moha Asri, 1999; Salleh and Ndubisi, 2006; Alias, 2007; Moha Asri and Manan, 2010; Yusoff and Yaacob, 2010) show that the government of Malaysia did play many important roles in the past to promote small business, yet Malaysian small business can improve more than what they are performing these days. However, it might be progressed further if the role of key people involved with these businesses would be understood properly. Add to this, few elements such as entrepreneurial demographic profile, their ability and skills, characteristic traits as well as their designation are the important concerns that have an influence on proper financial practice for a small business (Adeyemo, 2009), which employ business success ultimately.

Rudmann (2008) interpreted the term entrepreneurial skills as entrepreneurial qualities and/or values. Furthermore, the term 'skills, 'expertise, 'acumen' and 'competency' are all interrelated and are sometimes used interchangeably in the literature (Smith and Morse, 2005). Basically, these all make the entrepreneurial characteristic traits that mechanically come into contact with the financial means for the small business. Previously, Bird (1995) suggested that entrepreneurial skills like ownership skills and managerial skills can be as underlying characteristics such as generic and specific knowledge, motives, traits, self-images and social roles which result of growth and business success. A little later, Wickham (1998) added that the entrepreneurial skill means knowledge translates into the action. Most recently, Akande (2011) came up with a new understanding where the entrepreneurial skill is a quality or characteristic which needs to be possessed by entrepreneurs in starting and managing the business successfully. However, these skills can be found differently if the entrepreneurial role and authority are imposed differently (Adeyemo, 2009; Santos and Bode, 2012). At the same way, Malaysian small business may witness these different roles in terms of business owners and managers. 
Logically, a business owner does have more authority and freedom over business manager in operating a business. This research, therefore, investigate whether business owner and manager play different roles in financial practice towards business success in Malaysia. Moreover, this research investigates a completely different type of small business success from a different dimension, where the designation such as a business owner and manager play an important role. In this relation, this study embarks on the following objectives:

(i) To assess the impact of designation (owner) on Financial Practice towards Business Success.

(ii) To realize the impact of designation (manager) on Financial Practice towards Business Success.

(iii) To enhance the new understandings and recommend some potential implications for the business success of small business in Malaysia.

\section{Literature Review}

Small business includes all businesses and enterprises except large enterprises (Moha Asri, 1999; Moha Asri and Manan, 2010; Rosman and Mohd Rosli, 2011), because most of the businesses worldwide can be categorized as small businesses through judgmental reasoning (APEC, 2003). However, this definition also is also imposed in Malaysian perspective (Rosman and Mohd Rosli, 2011). Historically, there was no standard definition of small business used in Malaysia before the formation of the National SME Development Council (NSDC) in June 2004. Therefore, different agencies did characterize and define small business based on their own criteria, focusing on number of full-time employees and annual sales turnover mostly. According to a new definition approved recently on 11 July 2013, an enterprise with sales turnover of less than RM30 million and/or full-time employee of less than 200 in the manufacturing sector is considered small and medium size business (SME Corporation Malaysia, 2013).

In most industrially developed and developing economies, a growing number of small businesses need to access a wide range of sources of finance for their business success (Hussain et al., 2006). For that, financial knowledge and subsequent behaviour may bring the proper financial practice that employs business success for the small business (Xiang et al., 2011). It is widely recognized in academic literature that small businesses basically struggle with access to finance (Mason and Kwok, 2010; Hughes, 2009; Guijarro, Garcia and Auken, 2009; Bruns and Fletcher, 2008; Mason and Harrison, 2004) whereby financial practice can be indicated as the main player of the whole phenomena. Actually, access to finance helps and proper financial practice creates the business growth and prosperity for the small business (Stam and Garnsey, 2008; Butler and Cornaggia, 2009). However, Malaysia as like other developing countries, small business usually faces significant barriers to finance. This happens mainly because of an individual's knowledge, actions and behaviour regarding financial practices (Guiso and Minetti, 2010; Xiang et al., 2011).

For entrepreneurial knowledge and behaviour that constitute an organization's financial practice (Bellucci, et al., 2010; Dietrich, 2010; Hamelin, 2011; Xiang et al., 2011), the demographic profile of an entrepreneur is equally considered as a crucial factor that may lead their execution aptitude towards a specific action. Regarding this, Adeyemo (2009) stated that, skill is a quality of performance that is not only depended on individual natural ability but also must be developed through training, practice and experience. Although skill depends on learning and that learning brings more knowledge, it also includes the concepts of efficiency and economy in performance and/or success in the small business context.

The entrepreneurial affiliation and designation such as business owner and manager are the key components that should be considered while the primary concern is financial practice, and these should be taken into the account in exercising financial practice for business success. Effectively, components like entrepreneurial quality, ability, capacity, skills and overall characteristic traits derive from certain entrepreneurial features, while those typical features are the education, age, work experience and motivation (Guzman-Cuevas et al., 2009; Santos and Bode, 2012). As stated by Cooper (1985), work experience constitutes a learning process through entrepreneurial skills. This work experience can be gained from the authority and autonomy being exercised in the business enterprise either as owner or manager. These entrepreneurial skills are the basic skills necessary to enable entrepreneur to start, develop, finance and succeed in their enterprise (Adeyemo, 2009). However, Andersson and Tell (2009) focused on the firm's growth in respect with managerial traits and characteristics, managerial intentions, aspirations or motivation, as well as managerial behaviour or roles. Their conceptual model is principally based on earlier research on how owners and managers influence growth in small firms, where the direct relationship of managerial characteristic traits of business growth and success are observed.

Abu Mansor et al. (1999) explained managerial skills as the skill that is used to measure the manager's level of competency and effectiveness. According to Botha et al (2006), managerial skill involves skill in decision making, planning and strategy, human relation, finance, marketing, accounting, general management and negotiation. Likewise, 
Kadir and Rosli (2011) stated that, managerial skills consist of the three critical areas of skills, such as management, financial and marketing. This managerial skill is needed and also observed to the owners of the businesses as well. Therefore, when the measurement of financial practice is concerned for the business success, then the small business may scratch on management and ownership skills such as decision making ability, proper financial knowledge execution, appropriate financial behaviour and overall entrepreneurial character traits for the business success. Moreover, the difference in ownership and managerial roles still post a genuine concern in academia, which can be expressed through moderating effect. Derived from literature support and related evidences, this concern puts a conceptual framework which is exhibited in Figure 1.

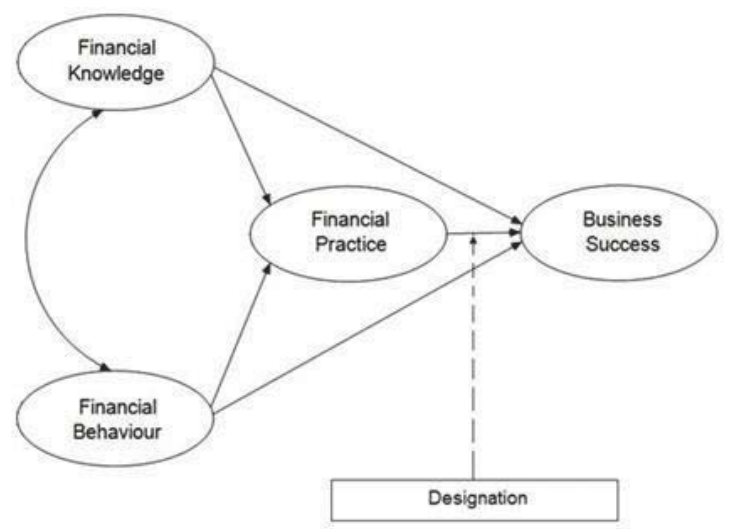

Figure 1: Conceptual Framework

To meet the research objectives and based on the conceptual framework presented above, two hypotheses are constructed as follows:

H1: There is a moderating effect of designation (owner) on financial practice towards business success.

$\mathrm{H} 2$ : There is a moderating effect of designation (manager) on financial practice towards business success.

\section{Research Methodology}

The research method of this study is survey method. The survey method is the most appropriate method for the data collection as this method helps to predict the nature of the total population from which the sample are selected (Fowler, 1988; Sapsford, 1999). Survey research method often leads to achieve the accuracy and relatively cost-efficient data for the research (Sekaran, 2000; Kothari, 2004). This method can be developed in less time and able to collect data from a large number of respondents (Neuman, 2007). Besides, the unit of analysis in this study is the individual respondent, such as business owners and managers involved in Malaysian small business. The sampling frame in this study contains the small businesses that are obtained from the SME Corp Malaysia. Since about majority of all the companies are based in Selangor and the greater Kuala Lumpur region, the capital city of Malaysia, thus it also reflected in the current study as well. Hence, the overwhelming majority of the companies had chosen from the Kuala Lumpur region for the current research, though some of the divisions of these companies are scattered in various parts of Malaysia.

This research used a 5- point Likert scale for constructing the questionnaire by putting preferences to the items considered in the past studies. Moreover, a 5-point Likert scale asks respondents to provide a relative assessment of various statements in the questionnaire on a continuum ranging from 'strongly disagree' to 'strongly agree' that are very commonly used for collecting primary data in empirical research (Ward et al., 1998).

To meet the research aim, this study employed the simple random sampling technique to carry out the survey. A simple random sampling is a subset of respondents (a sample) chosen from a larger set (a population). Each respondent is chosen randomly and exclusively with probability, wherein each of the respondent does have a similar possibility of being chosen at any phase throughout the sampling process (Malhotra, 2007; Sekaran and Bougie, 2009). For this purpose, the small businesses are chosen from the sampling frame representing the population are grouped into three broad categories derived from their business operation. These are as follows:

i. The businesses were selected did fulfil the criteria of small business and employ a regular basis operational activity. 
ii. The respondents who took part in this study comprised two categories including business owners and managers only.

iii. The respondents of being managers, they were working as the full-time employees in the respective enterprises, and who were familiar with the financial practice and other finance related activities.

Moreover, questionnaires were only distributed to the respondents having met the above criteria. As this research employs Structural Equation Modelling (SEM), therefore, the question of sample size adequacy remained as a prime concern in the application of SEM software program. A sample of 302 data was considered as the final sample size for the current study.

As mentioned, this research employs Structural Equation Modelling (SEM) for statistical analysis of data, which is developed for analysing the interrelationships among multiple variables in a model (Zainudin, 2012). Besides, SEM techniques have been significant to confirm theoretical models for using a quantitative approach. Therefore, evaluating these circumstances, this study considers SEM as a suitable tool for analysing quantitative data in research progression.

\section{Findings}

This section starts with demographic information of the respondents. The demographic information comprises the gender, age, race, level of education and respondents' designation in the respective company. This part, in fact, provides a detailed scrutiny of demographic information. Table 1 portrays the respondents' demographic information as a whole.

Table 1: Demographic Information on the Research Participants

$\begin{array}{ccc}\begin{array}{c}\text { Demographic Variable } \\ \text { Gender }\end{array} & \text { Frequency } & \text { Percentage } \\ \text { Male } & 178 & \\ \text { Female } & 124 & 58.9 \\ \text { Total } & 302 & 100.0 \\ & & \\ \text { Age } & & \\ <20 & 21 & 7.0 \\ 20-29 & 162 & 53.6 \\ 30-39 & 79 & 26.2 \\ \text { 40-49 } & 21 & 7.0 \\ \geq 50 & 19 & 6.3 \\ \text { Total } & 302 & 100.0 \\ & & \\ \text { Race } & & \\ \text { Malay } & 177 & 58.6 \\ \text { Indian } & 43 & 14.2 \\ \text { Chinese } & 82 & 27.2 \\ \text { Total } & 302 & 100.0 \\ \text { Level of Education } & & \\ \text { Primary School } & & \\ \text { Secondary School } & 29 & 9.6 \\ \text { Diploma } & 58 & 19.2 \\ \text { Bachelor } & 113 & 37.4 \\ \text { Masters Degree } & 78 & 25.8 \\ \text { Total } & 24 & 7.9 \\ & 302 & 100.0 \\ \text { Designation } & & \\ \text { Owner } & 129 & 42.7 \\ \text { Manager } & 173 & 100.0 \\ \text { Total } & 302 & \end{array}$

Above Table 1 shows that, both male and female are in good numbers participating in the study. Among 302 respondents, it is observed that, 178 are male where 124 are female, which means the percentages of male and female respondents are 58.9 percent and 41.1 percent respectively. Additionally, Table 1 also shows that the age range of 20-29 
years is 53.6 percent with the highest frequency of 162 and 30-39 years' age range covers 26.2 percent of total respondents having a second highest frequency of 79 out of 302. Besides, the age range of 40-49 years consists of 7.0 percent with 21 frequency as well as 50 years and above, which is coded as ' $\geq 50$ ' includes only 6.3 percent or 19 respondents out of 302 respondents. With the age diversity among respondents, there are diverse races like Malay, Indian and Chinese are also engaged with small businesses, where the engagement of Malay, Indian and Chinese are 58.6 percent, 14.2 percent and 27.2 percent respectively. Table 1 also indicates that 177 respondents (58.6 percent) are found Malay originated business owner or manager, while 43 respondents (14.2 percent) are Indian and another 82 respondents (27.2 percent) are Chinese. Hence, Chinese is having a better enterprise compared to Indian after Malay entrepreneurs.

Out of 302 respondents, 29 respondents (9.6 percent) passed primary school, 58 respondents (19.2 percent) completed secondary school, 113 respondents (37.4 percent) hold diploma, 78 respondents (25.8 percent) have a bachelor degree and only 24 respondents (7.9 percent) were with masters' degree with regard to educational qualification, where a total of 129 respondents (42.7 percent) are noticed as business owner, whereas 173 respondents (57.3 percent) are found as business manager among those 302 respondents.

Beside the demographic information, the company information draws an outline of a company or enterprise, which is basically a background of a venture. In this particular study, the company information indicates three major things covering types of business, length of operation and the number of employees. Table 2 presents the general information regarding the companies surveyed in the study.

Table 2: General Information of the Companies Surveyed

$\begin{array}{lcc}\text { General Information } & \text { Frequency } & \text { Percentage } \\ \text { Types of Business } & & \\ \text { Manufacturing } & 78 & 25.8 \\ \quad \text { Service } & 224 & 74.2 \\ \text { Total } & 302 & 100.0 \\ \text { Length of Operation } & & \\ \quad \leq 2 \text { Years } & 216 & 71.5 \\ >2 \text { Years } & 86 & 28.5 \\ \text { Total } & 302 & 100.0 \\ \quad & & \\ \text { Number of Employees } & 191 & 63.2 \\ \quad 55 & 111 & 36.8 \\ >5 & 302 & 100.0 \\ \text { Total } & & \end{array}$

Refer to the Table 2, the percentages of manufacturing and service industries are 25.8 percent and 74.2 percent respectively, where 78 enterprises are involved with manufacturing activities and 224 enterprises are engaged with service sectors, and there are 216 enterprises or 71.5 percent of businesses are operating their business less than two years, along with 86 enterprises or 28.5 percent of businesses are comparatively matured, having their business more than two years according to the respondents' statements. Table 2 also expresses the number of employees by definite numbers where 191 enterprises are found to have ' 5 employees and less', which is equivalent to 63.2 percent. On the other hand, rest of 111 enterprises (36.8 percent) are observed in the group of 'more than 5 employees' category.

After analysing the demographic and company information, the basic analysis (main model) was run via Structural Equation Modelling (SEM). In SEM, it is important to decipher whether, besides the main model, any other alternative or competing models cause of the moderating effects highlighting different speculative relationships among the latent constructs, offers better explanations of the phenomenon under study. The singular purpose is to compare these competing models derived by modifying the relationships either through segregating the groups or omission of paths (Hair et al., 2010). For this, the difference in Chi Square (ChiSq or $\chi^{2}$ ) test between two competing models is used to calculate improvements over competing models; significant results for the Chi Square (ChiSq or $\chi^{2}$ ) difference test indicate that the model with smaller Chi Square (ChiSq or $\chi^{2}$ ) has a statistically better fit (Milfont and Fischer, 2010). This is done, where the Chi Square (ChiSq or $\chi^{2}$ ) fit statistic is compared by difference in Chi Square (ChiSq or $\chi^{2}$ ) statistic such that ' $\Delta \chi^{2}$ (dfi - 
$\mathrm{d}$ (2) $=\chi^{2}(\mathrm{df1})-\chi^{2}(\mathrm{~d} 2)$, which is distributed as a chi-square distribution with $\mathrm{df}=\mathrm{df}_{1}-\mathrm{df}_{2}$ ' (Mueller and Hancock, 2007, $\mathrm{p}$. 501).

However, one of the objectives of this research is to discover whether there is any significant difference between the different designation such as enterprise owners and managers of the small business in understanding the relationship of financial practice and business success. To observe the moderating impact, SEM pursues a specific way to process the analysis. Initially, split of data is necessary into separate gatherings and spared into groups and this has to be saved in the different group name. At that point, two different models are produced utilizing two different data sets, where it needs to label with different names and there if there is no significant differences found between the models, it should go to the next stage of invariance analysis. After that, with getting the Chi Square (ChiSq or $\chi^{2}$ ) value for both the constrained and unconstrained models with respect to the Degrees of Freedom (df), the analysis computes whether the difference between the Chi Square $\left(\Delta \chi^{2}\right)$ and Degrees of Freedom is significant. If the difference seems significant, then it is clear that there is a difference between the two groups. On the other hand, if it is not significant, then those two models are identical and the nature of the respondent does not work as moderator in the model.

These phenomena, however, have been primarily tested by the following Figure 2 (a) and Figure 2 (b), which portray the unique response of the two groups of respondents in terms of their designation in the small business in Malaysia, namely enterprise owners and managers.

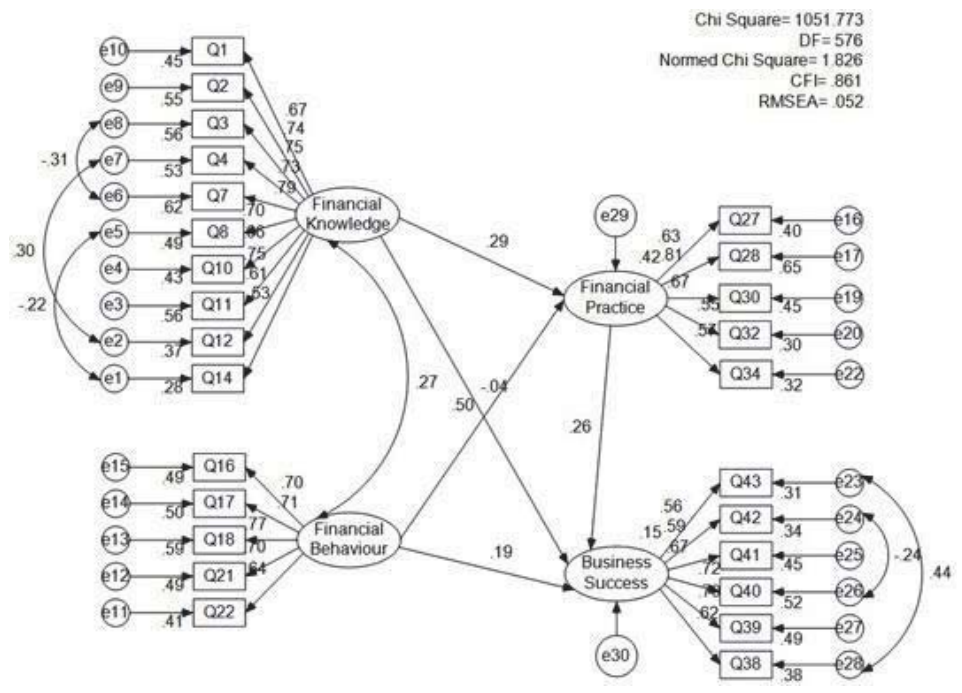

Figure 2 (a): Unique Response of Owners on the Hypothesized Model

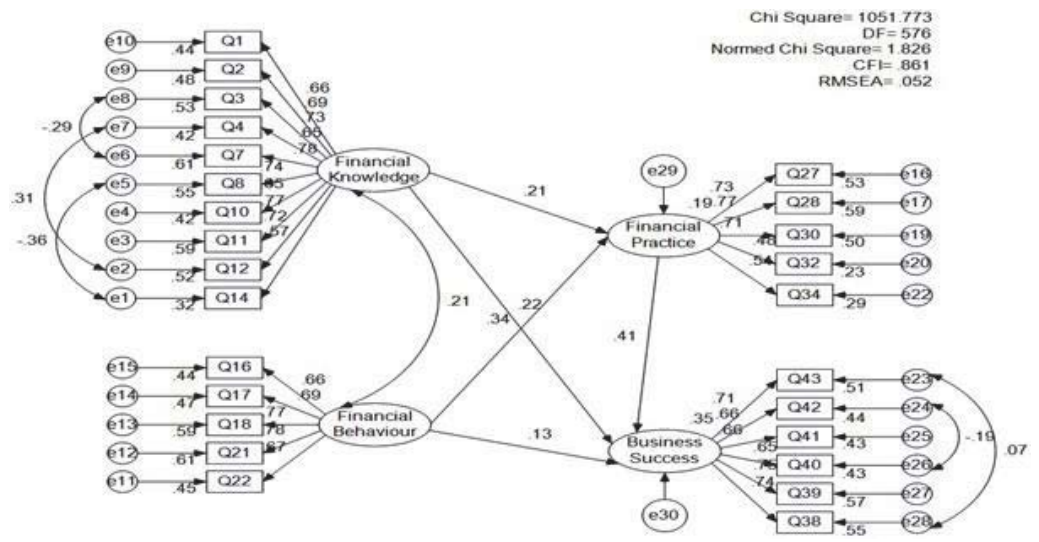

Figure 2 (b): Unique Response of Managers on the Hypothesized Model

Since both of these Figure 2 (a) and Figure 2 (b) show the same Chi Square (ChiSq or $\chi^{2}$ ), Degrees of Freedom (df), 
Normed Chi Square (ChiSq/df), CFI and RMSEA values, thus, no clear sign of having a moderating effect is observed. For this reason, it requires a move to the next stage of invariance analysis (Zainudin, 2012), allowing for both constrained and unconstrained models to figure it out whether the change of Chi Square (ChiSq or $\chi^{2}$ ) and the Degrees of Freedom (df) is significant between these two groups. According to Zainudin (2012), if the Chi Square (ChiSq or $\chi^{2}$ ) value changes between constrained and unconstrained models by more than 3.84 for 1 Degrees of Freedom (df), then the moderation occurs in that particular path. In this research, however, a parameter constraint is put on the selected path (Financial Practice $\rightarrow$ Business Success) to be equal to 1 as suggested by Zainudin (2012). Therefore, the Figure 3 (a) and Figure 3 (b) demonstrate the output for the constrained model and unconstrained model respectively for the enterprise owners.

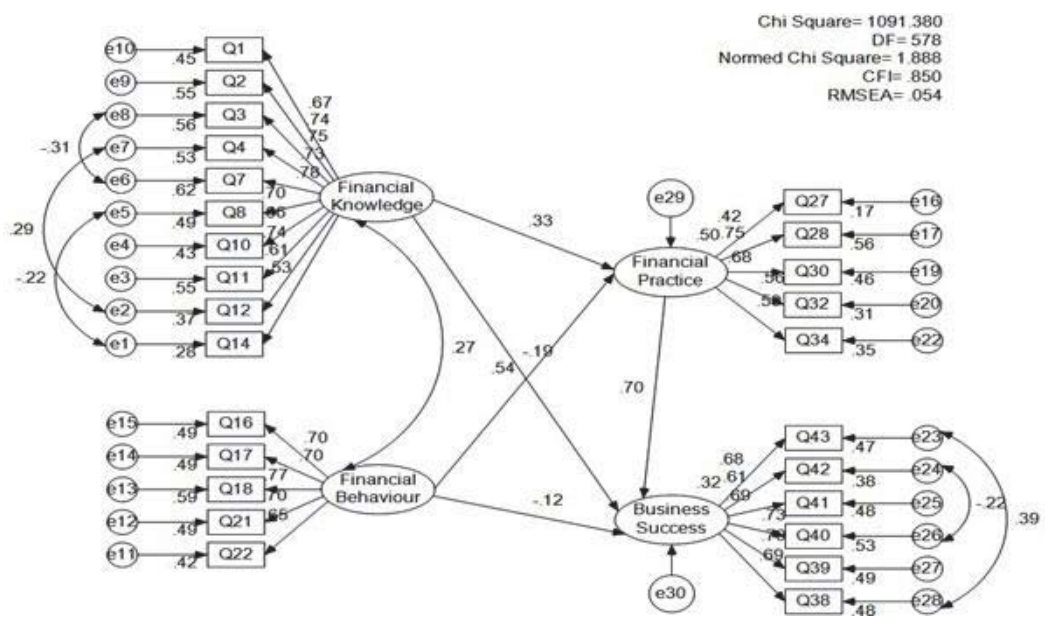

Figure 3 (a): Owners' Output for the Constrained Model

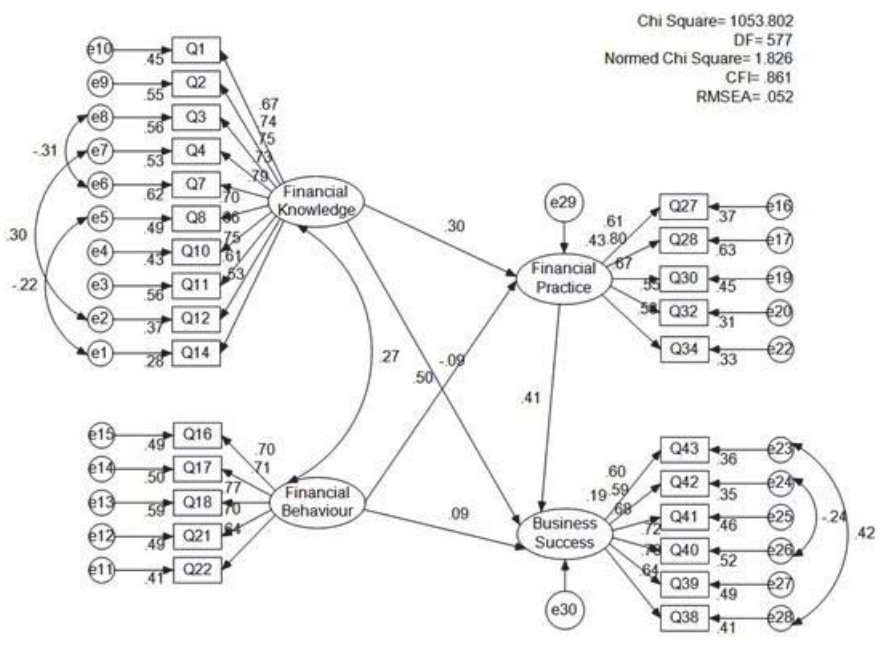

Figure 3 (b): Owners' Output for the Unconstrained Model

After this step of constrained model and unconstrained model analyses as shown in Figure 3 (a) and Figure 3 (b), now the different Chi Square (ChiSq or $\chi^{2}$ ), Degrees of Freedom (df), Normed Chi Square (ChiSq/df), CFI and RMSEA values are found. As a rule of thumb set by Zainudin (2012), the moderation happens in a particular path if the Chi Square (ChiSq or $\chi^{2}$ ) value changes above than 3.84 for 1 Degrees of Freedom (df) from the constrained model to the unconstrained model. However, following Table 3 shows the moderation test for enterprise owners' group data. 
Table 3: Moderation Test for Enterprise Owner

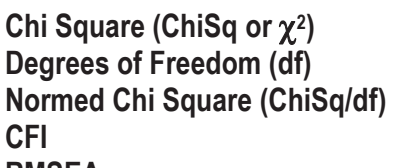

RMSEA

The Hypothesis Statement: $\mathrm{H1}$ : There is a moderating effect of designation (owner) on financial practice towards business success.

$\begin{array}{ccccc}\begin{array}{c}\text { Constrained } \\ \text { Model }\end{array} & \begin{array}{c}\text { Unconstrained } \\ \text { Model }\end{array} & \begin{array}{c}\text { Chi Square Difference } \\ \left(\Delta \chi^{2}\right)\left[\chi^{2}(\mathrm{df1})-\chi^{2}(\mathrm{~d} 2)\right] \\ 37.578\end{array} & \begin{array}{c}\text { Result in } \\ \text { Moderation } \\ \text { Significant }\end{array} & \begin{array}{c}\text { Result on } \\ \text { Hypothesis } \\ \text { Supported }\end{array} \\ 1091.380 & 1053.802 & 1 & & \\ 578 & 577 & & & \\ 1.888 & 1.826 & & & \\ 0.850 & 0.861 & & & \\ 0.054 & 0.052 & & & \end{array}$

Supported

The above Table 3 indicates that the moderation test is significant since the difference in Chi Square $\left(\Delta \chi^{2}\right)$ value between the constrained and unconstrained model is greater than 3.84. Actually, the difference in Chi Square (ChiSq) value is 37.578 (1091.380 - 1053.802), while the difference in Degrees of Freedom is $578-577=1$. Therefore, the hypothesized statement is supported. This is actually supported by Adeyemo (2009), who mentioned that the enterprise owners' profile, ability and skills, are the influential aspects that have a control on financial practice. In effect, components like entrepreneurial quality, ability, capacity, skills and overall characteristic traits are derived from certain owners' demographic features (Guzman-Cuevas et al., 2009; Santos and Bode, 2012). So, the result found from the Malaysian data is actually supporting the past literatures conducted in various businesses, while this research is evaluating small business in Malaysia.

On the other hand, as like constrained model and unconstrained model for the enterprise owners plotted in Figure 3 (a) and Figure 3 (b), the managers' constrained model and unconstrained model need to be tested subsequently since no clear indication was noted for a moderation effect from Figure 2 (a) and Figure 2 (b), seeing that the Chi Square (ChiSq or $\chi^{2}$ ), Degrees of Freedom (df), Normed Chi Square (ChiSq/df), CFI and RMSEA values were same between the groups. As a result, it calls for a further progress to the next stage of invariance analysis (Zainudin, 2012), addressing the both constrained and unconstrained models to observe whether the change of Chi Square (ChiSq or $\chi^{2}$ ) and the Degrees of Freedom (df) is significant. Therefore, a parameter constraint is put on the selected path (Financial Practice $\rightarrow$ Business Success) in the same way done before, where the parameter was fixed equal to 1 as suggested by Zainudin (2012). However, the Figure 4 (a) and Figure 4 (b) display the output for the constrained model and an unconstrained model for the enterprise manager respectively.

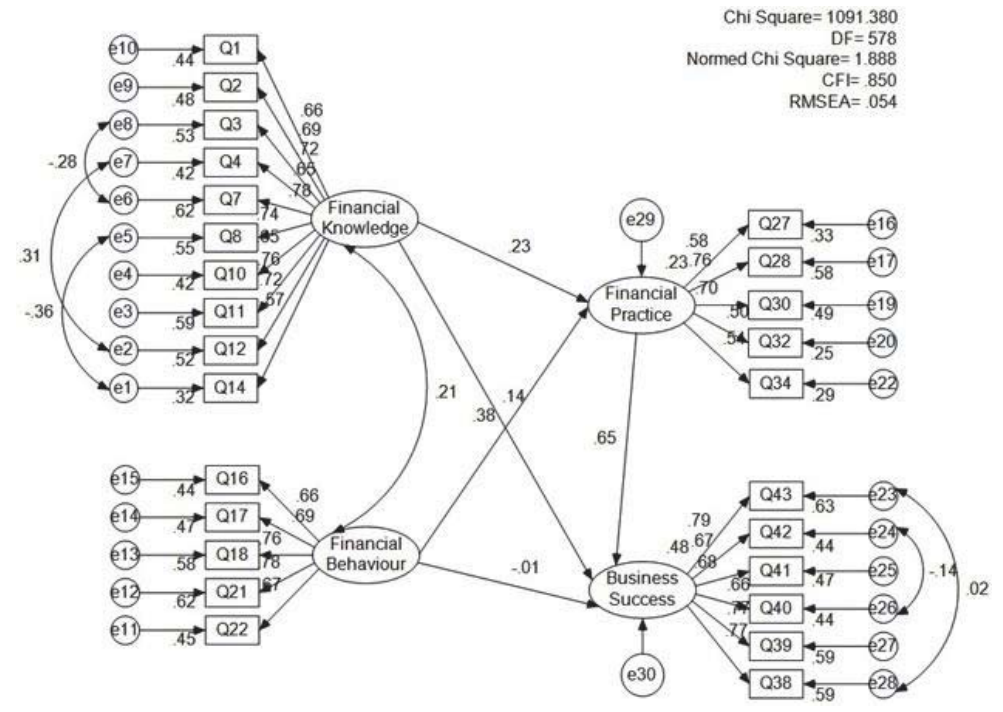

Figure 4 (a): Managers' Output for the Constrained Model 


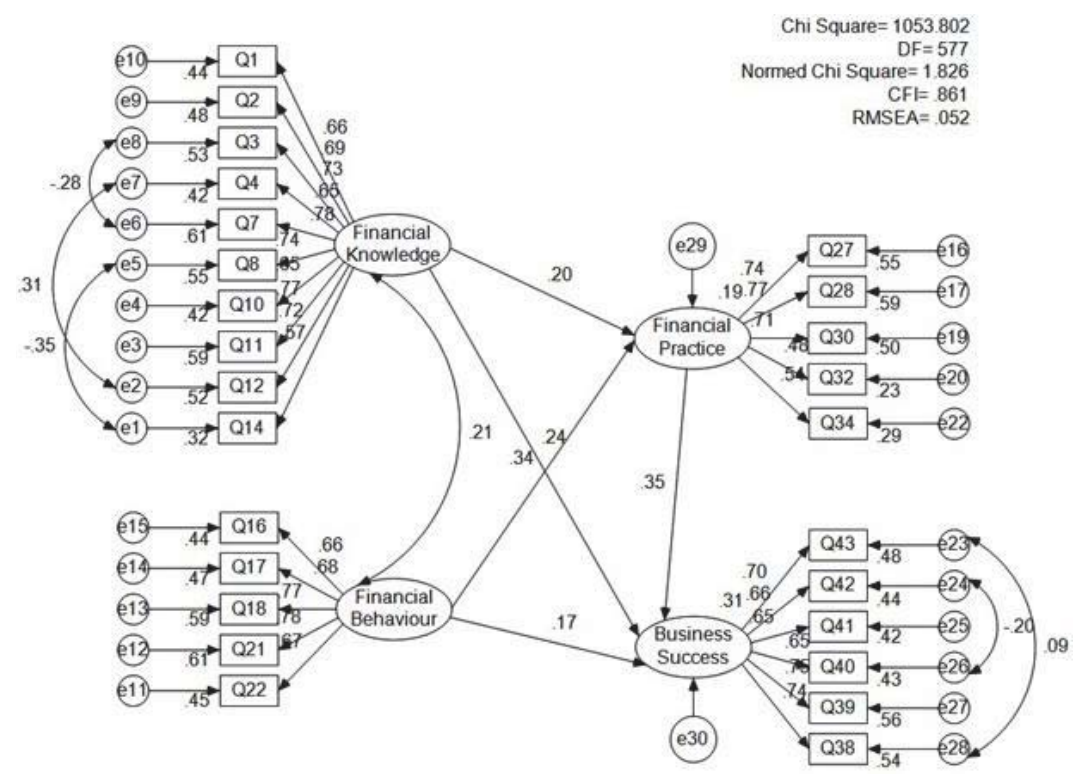

Figure 4 (b): Managers' Output for the Unconstrained Model

Just like previous analysis based on enterprise owner's, this step of constrained model and unconstrained model analyses also shows the different values for the Chi Square (ChiSq or $\chi^{2}$ ), Degrees of Freedom (df), Normed Chi Square (ChiSq/df), CFI and RMSEA as shown in Figure 4 (a) and Figure 4 (b). However, following Table 6.15 shows the moderation test for enterprise managers' group data.

Table 4: Moderation Test for Enterprise Manager

\begin{tabular}{|c|c|c|c|c|c|c|}
\hline \multirow{2}{*}{\multicolumn{2}{|c|}{ Chi Square (ChiSq or $\chi^{2}$ ) }} & Constrained Model & $\begin{array}{l}\text { Unconstrained } \\
\text { Model }\end{array}$ & $\begin{array}{l}\text { Chi Square Difference } \\
\left(\Delta \chi^{2}\right)\left[\chi^{2}(\mathrm{df1} 1)-\chi^{2}(\mathrm{~d} 2)\right]\end{array}$ & $\begin{array}{l}\text { Result in } \\
\text { Moderation }\end{array}$ & $\begin{array}{l}\text { Result on } \\
\text { Hypothesis }\end{array}$ \\
\hline & & 1091.380 & 1053.802 & 37.578 & Significant & Supported \\
\hline \multicolumn{2}{|c|}{ Degrees of Freedom (df) } & 578 & 577 & 1 & & \\
\hline \multirow{3}{*}{$\begin{array}{l}\text { Normed } \\
\text { (ChiSq/df) } \\
\text { CFI } \\
\text { RMSEA }\end{array}$} & Square & 1.888 & 1.826 & & & \\
\hline & & 0.850 & 0.861 & & & \\
\hline & & 0.054 & 0.052 & & & \\
\hline
\end{tabular}

The Hypothesis Statement: H2: There is a moderating effect of designation (manager) on financial practice towards business success.

One thing should be noted, although Table 3 and Table 4 exhibit similar results as well as given four figures such as Figure 3 (a), Figure 3 (b), Figure 4 (a) and Figure 4 (b) look like comparable, however, these all are unique since their path coefficients are different. From those path coefficients, actually the influences of the constructs can comprehend accordingly.

Observing the values from Table 4 above, it can be said that the moderation test is significant since the difference in Chi Square $\left(\Delta \chi^{2}\right)$ value between the constrained and unconstrained model is greater than 3.84 (Zainudin, 2012). Specifically, the difference in Chi-Square (ChiSq) value is 37.578 (1091.380 - 1053.802), while the difference in Degrees of Freedom is $578-577=1$. Therefore, the hypothesized statement is supported. Actually, some effective components like managerial quality, aptitude, capability, skills and overall characteristic traits derive from certain managerial demographic features (Abu Mansor et al., 1999; Bailey and Mitchell, 2007), those have an ultimate influence of having business success for the enterprise (Akande, 2011; Santos and Bode, 2012).

With these, therefore, it has been proved that there is a moderating effect of designation (owner and manager) on financial practice towards business success. In fact, previous scholarly works (Bellucci, et al., 2010; Dietrich, 2010; Hamelin, 2011; Haque, Rahman and Azam, 2011; Xiang et al., 2011) also support these findings that the owners and managers' diversified financial knowledge constitute an enterprise's financial practice wherein the demographic factors of 
the enterprise owners and managers' are uniformly considered as a crucial factor that may lead their business to be successful. In addition to this, owners and managers' skills are sort of 'quality of performance', which is not only depends on individual natural ability but also must be developed through training, practice and experience (Moha Asri, 1998; Adeyemo, 2009; Azam, Haque, Sarwar and Anwar, 2014). Although skill depends on learning and that learning brings more knowledge, it also includes the concepts of efficiency and economy in performance and/or success in the SMEs context.

\section{Discussion and Conclusions}

This study attempts to assess the moderating effect to test whether business owner and manager play different roles in financial practice towards business success in Malaysian small business. As mentioned earlier, the entrepreneurial quality, ability, capacity, skills and overall characteristic traits are derived from certain owners' demographic features (Adeyemo, 2009; Guzman-Cuevas et al., 2009; Santos and Bode, 2012), where a useful planned decision is thought as a centre of a firm's success (Olson et al., 2007). Usually, enterprise owners and managers are not found on the same boat since their decision making capacity does vary as well as the authority of leadership usually kept for the owners. However, the managers of an enterprise are considered as a substitute leader sometime, assuming to have better and more comprehensive decision maker (Lampikoski and Emden, 1999; Farrell et al., 2005), but according to findings, this phenomenon does not normally work in Malaysia. The result found from the Malaysian data is actually supporting many of the past literatures (Berry and Perren, 2001; Farrell et al., 2005; Gabrielsson, 2007; Olson et al., 2007; McCabe and Nowak, 2008; Boxer et al., 2013) in small businesses. Therefore, the hypothesized statements are supported, saying that the owners and managers' different moderating roles compose an enterprise's financial practice to guide the business success in the long run (Gabrielsson, 2007; Bellucci, et al., 2010; Dietrich, 2010; Hamelin, 2011; Boxer et al., 2013), which is true for Malaysia as well. However, this research used a valid and reliable instrument to measure the moderating effect to test whether business owner and manager play different roles in financial practice towards business success in Malaysian small business. Therefore, this study significantly contributed in the methodological development in the Malaysian small business. Conversely, on the practical execution level of financial matters, this study mainly focuses on individuals (owners and managers) those who directly and indirectly handle the financial substances. As mentioned earlier, the respondents of this research were the enterprise owners and managers to get the internal, financial and operational information. This will definitely increase the efficiency which would be the ultimate step for business win for any business, as to small business in Malaysia.

\section{References}

Abu Mansor, A., Ahmad, F., Din, M., Hanissah A. R, \& Mohd Noor, N. A (1999). Pengantara Pengurusan. Sintok: Universiti Utara Malaysia.

Adeyemo, S. A (2009). Understanding and acquisition of entrepreneurial skills: A pedagogical re-orientation for classroom teacher in science education. Journal of Turkish Science Education, 6 (3), 57-65

Akande, O. O. (2011). Accounting skills as a performance factor for small businesses in Nigeria. Journal of Emerging Trends in Economics and Management Sciences, 2 (5), 372-378. Retrieved May 16, 2013, from: www.jetems.scholarlinkresearch.org

Alias, A. (2007). Entrepreneur and entrepreneurship Fundamentals of Entrepeneurship. Petaling Jaya: Prentice Hall.

Andersson, S., \& Tell, J. (2009). The relationship between the manager and growth in small firms. Journal of Small Business and Enterprise Development, 16 (4),586 - 598.

APEC. (2003). What is an SME? SME definitions and statistical issues. Journal of Enterprising Culture, 11(3), 173-183.

Azam, S. M. F., Haque A., Sarwar, A. and Anwar, N. (2014), "Training Program Effectiveness of Service Initiators: Measuring Perception of Female Employees of Bank Using Logistic Approach", Asian Research Journal of Business Management, Vol. 2 No.1, pp.98108

Bailey, J., \& Mitchell, R. B. (2007). Industry perceptions of the competencies needed by computer programmers: technical, business, and soft skills. Journal of Computer Information Systems, (Winter), 28-33.

Bellucci, A., Borisov, A, \& Zazzaro, A. (2010). Does gender matter in bank-firm relationships? Evidence from small business lending, Journal of Banking \& Finance, 34, 2968-2984.

Berry, A. and Perren, L., (2001), "The role of non-executive directors in UK SMEs", Journal of Small Business and Enterprise Development, Vol. 8 Iss 2 pp. 159-173

Bird, B. (1995). Toward a theory of entrepreneurial competency. In Katz, J.A. and Brockhaus, R.H. (Ed.) Advances in Entrepreneurship, Firm emergence, and Growth, JAI Press, Greenwich, CT, 2, 51-72.

Botha, M, Nieman, G., \& Vuuren, J. V. (2006). Enhancing female entrepreneurship by enabling access to skill. EntrepreneurshipManagement, 479-493. 
Boxer, R., Perren, L. and Berry, A., (2013), "SME top management team and non\#executive director cohesion", Journal of Small Business and Enterprise Development, Vol. 20 Iss 1 pp. $55-79$

Bruns, V., and Fletcher, M. (2008). Banks' risk assessment of Swedish SMEs. Venture Capital, 10 (2). pp. 171-194.

Butler, A., \& Comaggia, J. (2009). Does access to extemal finance improve productivity? Evidence from a natural experiment. Journal of Financial Economics, 99 (I), 184-203.

Cooper, A C. (1985). The role of incubator organizations in the founding of growth- oriented firms. Journal of Business Venturing, 1 (1),75-86.

Dietrich, A. (2010). Explaining loan rate differentials between small and large companies: evidence from Switzerland, Small Business Economics, DOI: 10.1007/s11187-010-9273-8.

Farrell, J.B., Flood, P.C., Mac Curtain, S., Hannigan, A., Dawson, J. and West, M. (2005), "CEO leadership, top team trust and the combination and exchange of information", Irish Journal of Management, Vol. 26 No. 1, pp. 22-40.

Fowler, F. J. (1988). Survey research methods. California: Newbury Park, Sage.

Gabrielsson, J. (2007), "Boards of directors and entrepreneurial posture in medium-sized companies", International Small Business Journal, Vol. 25 No. 5, pp. 511-37.

Guijarro, A., Garcia, D. and Auken, H., (2009). Barriers to Innovation among Spanish Manufacturing SMEs. Journal of Small Business Management, 47 (4), 465-488.

Guiso, L \& Minetti, R. (2010). The structure of multiple credit relationships: evidence from U.S firms, Journal of Money, Credit \& Banking, 42(6), 1037-1071.

Guzman-Cuevas, J., Caceres-Carrasco, R., \& Riberio-Soriano, D. (2009). Functional dependence and productive dependence of SMEs. Small Business Economics, 32 (3), 317-330. Retrieved December 12, 2012, from: www.mpra.ubunimuenchen.de/4394/1/MPRApaper-4394.pdf

Hamelin, A. (2011). Small business groups enhance performance and promote stability, not expropriation. Evidence from French SMEs, Journal of Banking \& Finance, 35, 613-626.

Haque, A., Rahman, S., and Azam, S. M. F. (2011), "Application of Ethics in Small Enterprise: An Empirical Study on Dhaka City in Bangladesh". Indian Journal of Management, Vol.4 No.3, pp.45-51

Hughes, A. (2009). Hunting the shark: some reflections on the UK experience of support for the small business sector. Innovation: Managllment, Policy and Practice, 11 (2), 114-26.

Hussain, J., Millman, C., \& Matlay, H. (2006). SME financing in the UK and in China: a comparative perspective. Journal of Small Business and Enterprise Development, 13 (4), 584-599. Retrieved February 20, 2013, from: www.emeraldinsight.com/14626004.htm

Kadir, S. A., \& M. Rosli, M. (2011). Managerial skills of the small indigenous entrepreneurs in Malaysia. International Journal of Business and Social Science, 2 (10), 209-217.

Khairudin, H. (Ed.). (2007). Small and Medium-sized Entreprises Development in Malaysia: Programs and evaluation. Sintok: Universiti Utara Malaysia.

Kothari, C. R. (2004). Research Methodology: Methods and Techniques (2nd ed.). New Delhi: New Age International Publishers.

Lampikoski, K. and Emden, J.B. (1999), Managing Innovatively: Exploit Creative Resources, WSOY, Porvoo.

Lim, C. P. (1986). Small Industry in Malaysia. Kuala Lumpur: Berita Publishing Sdn Bhd.

Malhotra, N. K. (2007). Marketing Research: An Applied Orientation. 5th ed., Upper Saddle River, NJ: Prentice-Hall.

Mason, C., \& Harrison, R. (2004). Business angel networks and the development of informal venture capital market in the UK: is there still a role for public policy? Small Business Economics, 9, 111-123.

Mason, M., \& Kwok, J. (2010). Investment readiness programmes and access to finance: a critical review of design issues. Local Economy, 25 (4), 269-292.

McCabe, M. and Nowak, M., (2008), "The independent director on the board of company directors", Managerial Auditing Journal, Vol. 23 Iss 6 pp. 545-566

Moha Asri, Abdullah and Siti Khadijah A. Manan (2010). Adequacy of Financial Facilities for Small-Medium Businesses: Empirical Findings from Malaysia. Journal of International Review of Business and Research Papers. 6 (4), 535-548.

Moha Asri, Abdullah. (1998). Perception of the Entrepreneurs of Small-Medium Industries towards Training in Malaysia. Industry and Higher Education. Vol. 12, pp.115-122.

Moha Asri, Abdullah. (1999). Small and Medium Enterprises in Malaysia: Policy Issues and Challenges, Vermont, Ashgate.

Neuman, W. L. (2007). Basic of Social Research: Qualitative and Quantitative Approaches (2nd ed). New York: Pearson Education, Inc.

Olson, B.J., Parayitam, S. and Bao, Y. (2007), "Strategic decision: the effects of cognitive diversity, conflict and trust on decision outcomes", Journal of Management, Vol. 33 No. 2, pp. 196-222.

Rosman, M., \& Mohd Rosli, M. (2011c). Perusahaan Kecil don Dilema Usahawan Melayu. Kuala Lumpur: Penerbit Universiti Malaya.

Rudmann, C., (2008), Entrepreneurial Skills and their Role in Enhancing the Relative Independence of Farmers. Results and Recommendations from the Research Project Developing Entrepreneurial Skills of Farmers. Research Institute of Organic Agriculture, ISBN 978-3-03736-028-6, Frick, Switzerland.

Salleh, A. S., \& Ndubisi, N. O. (2006). An Evaluation of SME Development in Malaysia. International Reviewof Business Research Papers, 2(1), 1-14.

Santos, F M., \& Bode, C. S. (2012). The organizational foundations of corporate social entrepreneurship Working Paper. Retrieved March, 20, 2013, from: http://www.insead.edu/facultyresearch/research/doc.cfm?did=51663 
Sapsford, R. (1999) Survey Research. London: Sage.

Sekaran, U. (2000). Research Methods for Business: A Skill Building Approach (3rd Ed). New York: John Wiley \& Sons.

Sekaran, U. and Bougie, R. (2009). Research methods for business: a skill-building approach (5 $5^{\text {th }}$ ed.). Haddington: John Wiley \& Sons.

SME Annual Report. (2012). Retrieved April 1, 2013, from: http://www.smeinfo.com.my/index.pbp?option=com_content\&view= article\&id=1415\&ltemid1312\&langen

SME Corporation Malaysia. (2013). Retrieved May 11, 2013, from: http://www.smeinfo.com.my/index.pbp/en/sme-definition/developingmalaysian-smes/importance-of-smes

Smith, B., \& Morse, E. (2005). Entrepreneurial competencies: literature review and best practices, Small Business Policy Branch, Industry Canada, Ottawa

Stam, E., \& Garnsey, E. W. (2008). Entrepreneurship in the Knowledge Economy. Centre for Technology Management (CTM) Working Paper, No. 2007/04. Retrieved September, 2012, from: http://dx.doi.orgrl0.2139/ssm.1923098

Ward, P. T., McCreery, J. K., Ritzman, L. P., \& Sharma, D. (1998). Competitive Priorities in Operations Management. Decision Sciences, 29 (4), 1035-1046.

Wickham, P. A. (1998). Strategic entrepreneurship: A decision-making approach to new venture creation in management. London: Pitman.

Xiang, D., Worthington, A. C \& Higgs, H., (2011). Firm-level determinants and impacts of finance-seeking behaviour and outcomes for small and medium-sized enterprises (SMEs) in Australia. Discussion Papers in Finance: 201115, Griffith University, Department of Accounting, Finance and Economics.

Yusoff, M. H. And Yaacob, M. R., (2010). The Government Business Support Services in Malaysia: The Evolution and Challenges in the New Economic Model, International Journal of Business and Management, 5 (9), 60-71.

Zainudin, A. (2012). A Handbook on SEM: Structural Equation Modelling Using Amos Graphics (4th ed.). Kelantan: University Technology MARA Press. 